\title{
CARING FOR NATURE: FROM FACT TO VALUE, FROM RESPECT TO REVERENCE
}

by Holmes Rolston, III

\begin{abstract}
Despite the classical prohibition of moving from fact to value, encounter with the biodiversity and plenitude of being in evolutionary natural history moves us to respect life, even to reverence it. Darwinian accounts are value-laden and necessary for understanding life at the same time that Darwinian theory fails to provide sufficient cause for the historically developing diversity and increasing complexity on Earth. Earth is a providing ground; matter and energy on Earth support life, but distinctive to life is information coded in the genetic molecules that superintends this matter-energy. Life is generated and regenerated in struggle, persists in its perishing. Such life is also a gift; nature is grace. Biologists and theologians join in celebrating and conserving the genesis on Earth, awed in their encounter with this creativity that characterizes our home planet.
\end{abstract}

Keywords: environmental conservation; evolutionary natural history; fact/value distinction; genetic information; nature as grace; order versus contingency; respect for nature; reverence for nature.

There is often thought to be a great divide between fact and value, two words paired in my title, the famous gap marked by the "naturalistic fallacy." The second pair of words, respect and reverence, may be thought to be closely entwined. Generally I will here entwine the first two more than many readers may be comfortable with and distinguish the second two more than readers might expect. Respect is but a preamble to reverence. Three of these words—-value, respect, and reverence-are likely to elicit

Holmes Rolston, III, is University Distinguished Professor and Professor of Philosophy at Colorado State University, Fort Collins, CO 80523. He was Templeton Prize laureate in 2003.

[Zygon, vol. 39, no. 2 (June 2004).]

(C) 2004 by the Joint Publication Board of Zygon. ISSN 0591-2385 
the first word of my title, caring. Along the way I will look at some bridge words: awe, wonder, and the sublime.

How do we rise from the facts of natural history, Earths biodiversity, to what ought to be, human caring for a valuable creation? Notice, first, that the signs posted that forbid trespassing this boundary are themselves cultural artifacts, deriving from certain theories about ethics, the moral neutrality of nature, or value as human-interest satisfaction. Experienced naturalists often are inclined to ignore signs about where one can and cannot legitimately go, I cannot promise to provide you with a formal logic across the fact/value gap, but I can give you a good story-exciting natural history. There is something awesome about an Earth that begins with zero and runs up toward 5 to 10 million species in several billion years, setbacks notwithstanding. Something about the long evolutionary toil gives us cause to hope that this drama will continue. That history seems valuable; it commands respect, even reverence.

Now we confront another alleged fallacy, the "genetic fallacy." One cannot move value judgments back and forth from present to past. One does not dismiss the greatness of Abraham Lincoln as president by discovering that he was born in the back woods. One does not dismiss a scientific theory by discovering that it originated in idiosyncratic circumstances. One cannot undermine presently encountered value-so this argument goes-by discovering that it had uncertain origins. Can we not remain puzzled about origins while we greatly respect what we now find on Earth?

One does not have to go so "deep down" to know the "native range" worth. A husband can respect his wife while not knowing what kind of proteins she is made of, much less that she is made of quarks or that her ancestors evolved over millennia of natural selection. Possibly we can know that value is present without knowing its origins. Still, in historical events, processes such as speciation do not separate easily from products such as species. Upon finding a goose that lays golden eggs, it would be odd to admire the eggs and ask no questions about the goose.

\section{BIODIVERSITY AND PLENITUDE OF BEING}

Something is increasingly learned across evolutionary history: how to make more kinds and more-complex kinds. This seems to be an undeniable truth about natural history, although we next wonder how far neo-Darwinism, the prevailing paradigm, is competent to provide an adequate explanation for how this happens. We do not think that there is any progress as the planets spin around the sun or gases swirl around Jupiter. There is none on Earth with the passing of cold and warm fronts; they just come and go. Likewise with the rock cycles, orogenic uplift, erosion, and uplift again.

But there is no natural selection there either-nothing is competing, nothing is surviving, nothing has adapted fit. Biology seems different. 
Climatological and geomorphological agitations continue in the Pleistocene period more or less as they did in the Precambrian, but the life story is not the same all over again. Where once there were no species, now there are five to ten million. It seems evident that, on average and environmental conditions permitting, the numbers of life forms start low and end high. Diversity increases.

So does complexity. With genetic evolution, organisms gain the capacity to acquire new information over historical time and to store and transmit this information. All of them start simple, and some end up complex; there are trends over longer-range time scales, and something is at work in addition to the mere tracking of drifting environments. The life process is drifting through an information search and locking onto discoveries. It is cybernetic or hereditary, as geomorphic processes are not. There is no cumulation of information in the hydrologic, climatological, orogenic cycles, but there is in the birth, life, death, genetic cycles. Biology is historical in ways impossible in physics or geophysics.

Ernst Mayr, though he realizes that higher is a troublesome word in biology, still asks:

And yet, who can deny that overall there is an advance from the procaryotes that dominated the living world more than three billion years ago to the eucaryotes with their well organized nucleus and chromosomes as well as cytoplasmic organelles; from the single-celled eucaryotes to metaphytes and metazoans with a strict division of labor among their highly specialized organ systems; within the metazoans from ectotherms that are at the mercy of climate to the warm-blooded endotherms, and within the endotherms from types with a small brain and low social organization to those with a very large central nervous system, highly developed parental care, and the capacity to transmit information from generation to generation? (Mayr 1988, 251-52)

David Raup and John Sepkoski (1982) graph a rise, again with climbs and drops, especially at times of catastrophic extinctions, from zero to perhaps 750 families (Fig. 1). During the relatively flat part of the marine curve, one should notice, life moves onto the land and greatly diversifies there, from the Silurian Period onward (not shown in this graph). That requires also considerable evolution of complexity, since the terrestrial environment is more demanding. Plants develop steadily on the land masses, graphed by Karl Niklas (Fig. 2). For animals, it is in the vertebrates, most of all, that advancement is difficult to deny (Fig. 3) (Niklas 1986; 1997).

Norman D. Newell (1963) graphed the numbers of all families-terrestrial and marine, vertebrate and invertebrate-increasing through evolutionary time (Fig. 4). Nothing seems more evident over the long ranges than that complexity has increased. In the Precambrian there were microbes; in the Cambrian trilobites were the highest life form; the Pleistocene produced persons. Francisco J. Ayala concludes, "Progress has occurred in nontrivial senses in the living world because of the creative character of the process of natural selection" $(1974,353)$. 


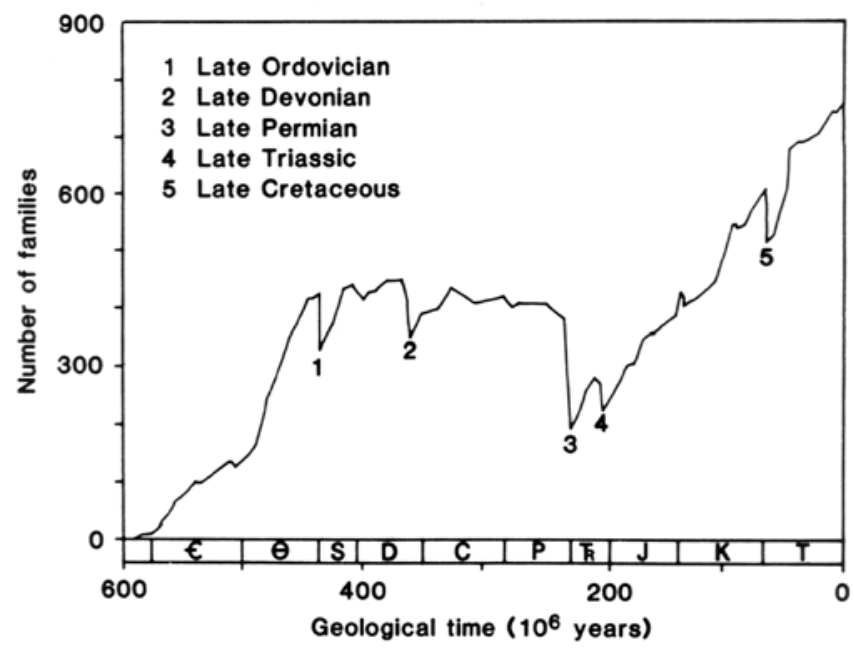

Fig. 1. Standing diversity through time for families of marine vertebrates and invertebrates, with catastrophic extinctions numbered (Raup and Sepkoski 1982, 1502). Reprinted with permission from Science 215:1501-03. Copyright (C1982 AAAS.

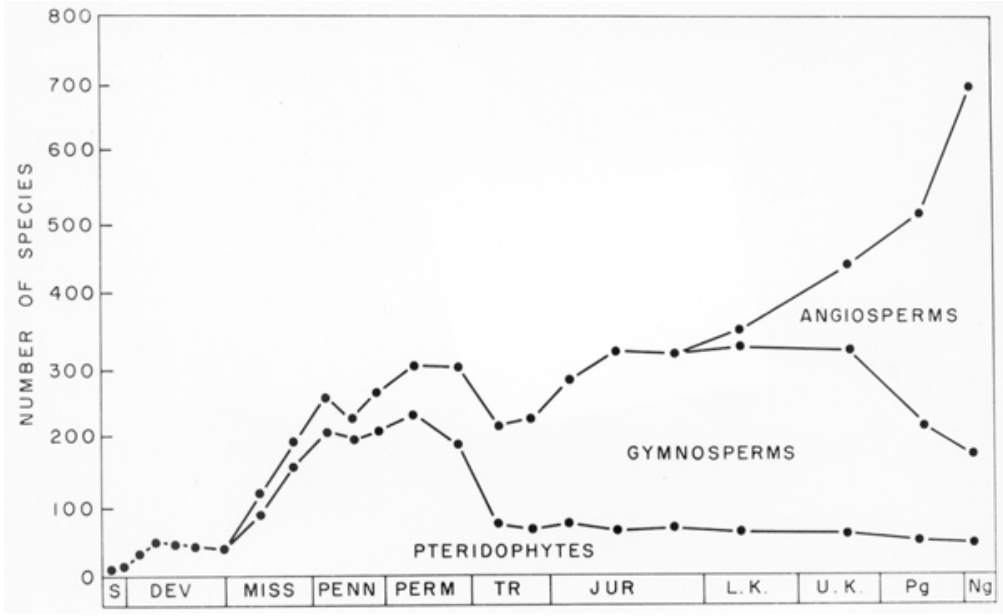

Fig. 2. Species diversity changes in vascular plants (Niklas 1986, 385). Copyright (C1986 Springer-Verlag. Reprinted with permission. 
Against this background, we acknowledge the current fashion among social constructionists and postmodernists to think that any such increase of complexity or diversity is just British aristocrats reading their metaphysics back into nature. A scholar's chosen opinions reflect his or her social and cultural climate as much as they do what is objectively there in the fossil record. One takes ones mood from whatever spirits are at large on the contemporary academic landscape, insist the social constructionists (without conceding that they too are among such spirits).

On this point philosophers of science and even the paleontologists themselves may nowadays join the social constructionists. Michael Ruse insists, "Evolution is going nowhere-and rather slowly at that" (1986, 203). Although most paleontologists over the last century have seen progress in evolutionary history, this is pseudoscience, an overlaying of European ideologies onto the fossil record (Ruse 1996, 526).

Stephen Jay Gould, the most visibly outspoken paleontologist of the last century, insists that belief that there is "inherent, stately progress as a hallmark of life's history" is foolish prejudice. "The history of life . . . is not going anywhere intrinsically" (Gould 19S0a, 31-32). "We are the

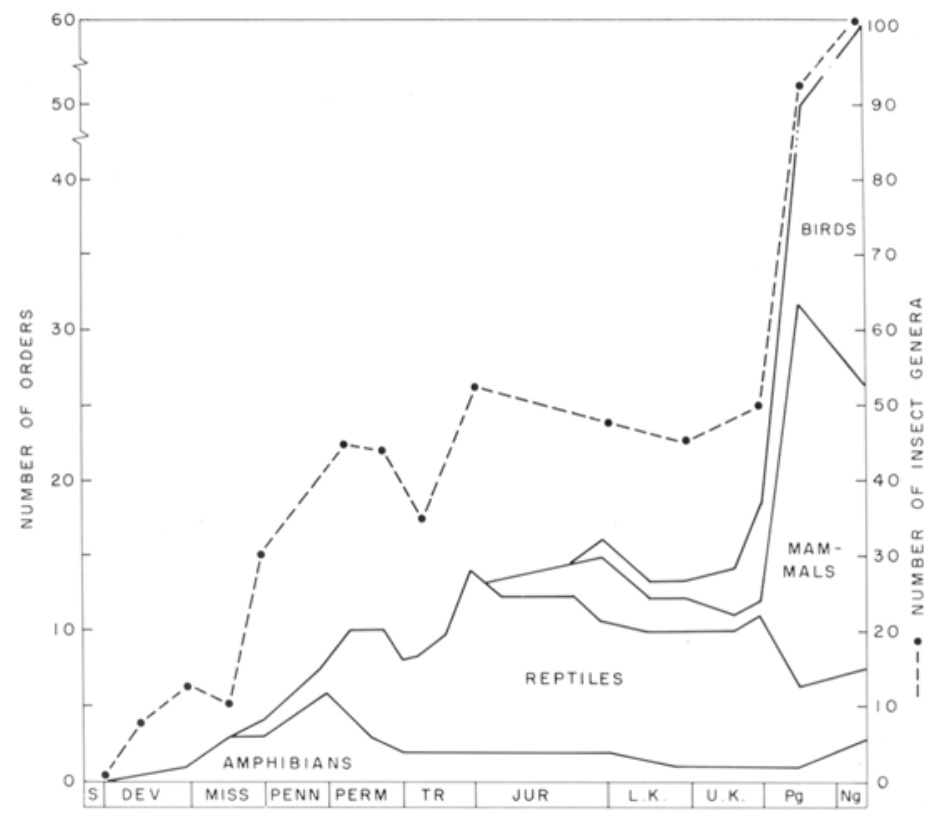

Fig. 3. Changes in the composition of vertebrate orders and numbers of insect genera (Niklas 1986, 390). Copyright (c1986 Springer-Verlag. Reprinted with permission. 
accidental result of an unplanned process ... the fragile result of an enormous concatenation of improbabilities, not the predictable product of any definite process" (Gould 1983, 101-2). Biology has no covering law, or trend, enabling one to say that microbes, or mammals, or human beings could statistically be expected. Evolutionary theory offers no explanation of the crucial journey; indeed, it claims that there is none, that the results are random. All that is selected for is the capacity to survive, unrelated to any increase of worth or value.

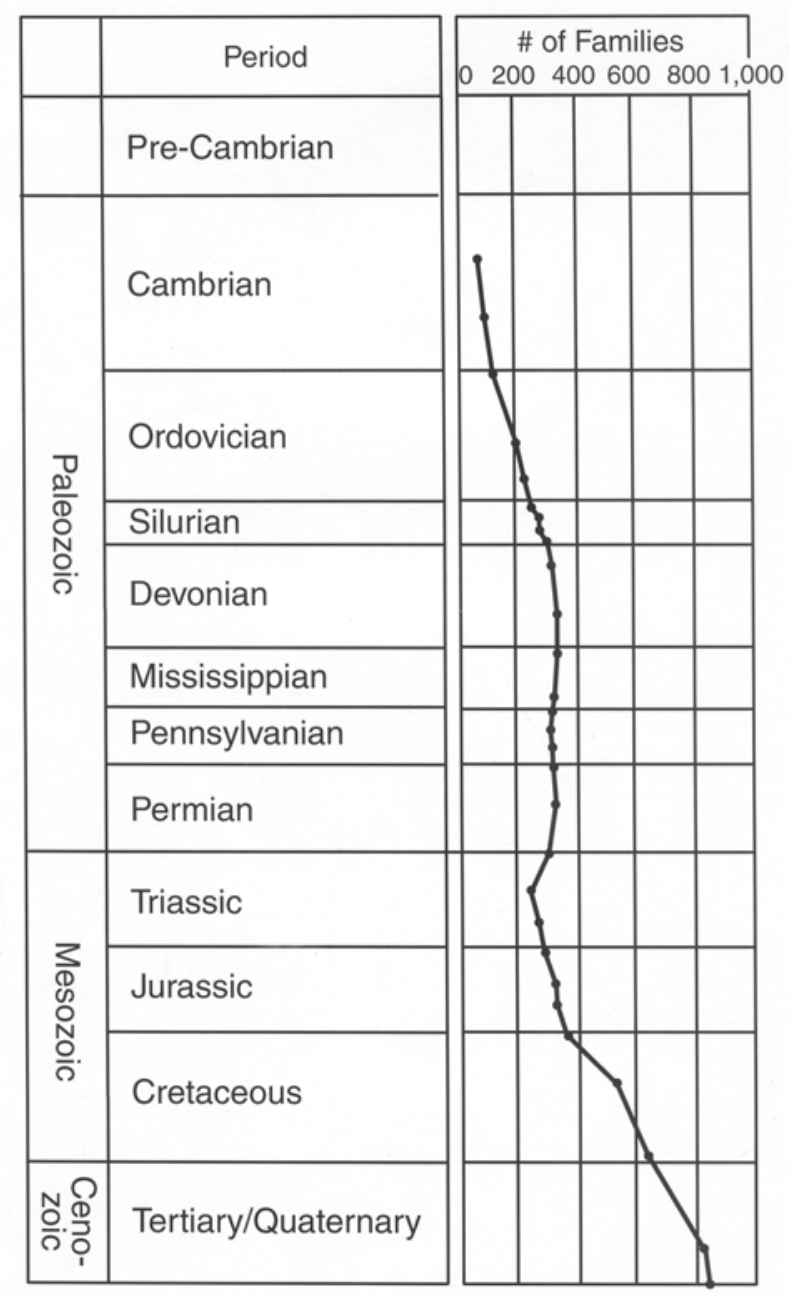

Fig. 4. Number of major families of fossil animals increasing through time. (Newell 1963, 80). Reprinted with permission. 
Perhaps the philosophical interpretation of these graphs is not science; nevertheless we have a metaphysical problem on our hands as a result of the science. John Maynard Smith says, "There is nothing in neo-Darwinism which enables us to predict a long-term increase in complexity." But he goes on to suspect that this is not because there is no such long-term increase but because Darwinism is inadequate to explain it. We need "to put an arrow on evolutionary time" but get no help from evolutionary theory. "It is in some sense true that evolution has led from the simple to the complex: procaryotes precede eucaryotes, single-celled precede manycelled organisms, taxes and kineses precede complex instinctive or learned acts. I do not think that biology has at present anything very profound to say about this" (Maynard Smith 1972, 89, 98).

We survey evolutionary history to find, to use an old category, plenitude of being. The modern term is biodiversity. If you want a still older, more earthy term, Earth has brought forth "swarms of living creatures" (Genesis 1:20 RSV). The long evolutionary creativity seems pretty much the fact of the matter, see it with what social constructions we may.

\section{DARWINIAN NATURE AND SUFFICIENT CAUSE}

Perhaps one does not need to go "all the way down," but it will enrich our valuing and our ethics if we can go "all the way up"-that is, if we can gain some systemic, comprehensive view. "Down under the quarks" may be a bad analogy. One might need to know the origin or context of some values to authenticate these values. One might need to know, for example, whether one's wife is made in the image of God to treat her with full respect. Value will be piecemeal without a system, a grand narrative. At least we need, in Maynard Smith's metaphor, a phylogenetic "arrow."

Without systemic tendencies, the biological richness we find on Earth is an anomaly, a cascading value stacking that cannot be predicted, derived, or given account of out of the theoretical model. If the species one encounters are results of being buffeted about by random winds of change, if their adaptation to the drifting environments is by variations arising from a genetic "crapshoot," then one may by good fortune luck into spasmodic wealth, but one is not systemically wealthy. The biodiversity we find ourselves surrounded with is, Gould insists, only "chance riches" (1980b).

A person who has riches by chance (a winning lottery ticket) is less wealthy than one with riches who has earned them, or one who inherited them from a family with decades of hard work and achievements. Certainly, you can value what you have through luck. But if you just luck into all your goods, you have no cause to expect more value and no explanation for what you have. A person who finds on Earth only accidental riches is less wealthy than one who inhabits a system bent on enriching the diversity of life. Lucky people may still be inclined to respect their wealth, but 
they will unable to respect any system that produced such wealth. Without any phylogenetic arrow, they are as likely to drift out of their wealth as to be aimed for more. They might respect life, but they are unlikely to reverence it, because they do not have any account of its origins or matrix in the scheme of things.

Did not Maynard Smith complain that increase of complexity, an arrow on evolutionary time, seemed a fact about which contemporary theoretical biology had little to say? Biology does have some things to say about life. One cannot construct life (as we know it, at least) without carbon, hydrogen, and oxygen atoms and without a source of energy such as the Sun. One cannot construct complex forms without beginning with simpler ones. In such biological theory we have necessary cause but find no sufficient cause.

Maynard Smith and Eörs Szathmáry analyze "the major transitions in evolution" with the resulting complexity, asking "how and why this complexity has increased in the course of evolution. ... Our thesis is that the increase has depended on a small number of major transitions in the way in which genetic information is transmitted between generations." Critical innovations have included the origin of the genetic code itself, the origin of eukaryotes from procaryotes, meiotic sex, multicellular life, animal societies, and language, especially human language. But they find "no reason to regard the unique transitions as the inevitable result of some general law"; to the contrary, these events might not have happened at all (Maynard Smith and Szathmáry 1995, 3).

Meanwhile, biology is value-laden. Biologists talk about values all the time. "An ability to ascribe value to events in the world, a product of evolutionary selective processes, is evident across phylogeny. Value in this sense refers to an organism's facility to sense whether events in its environment are more or less desirable" (Dolan 2002, 1191). Adaptive value, survival value, is the basic matrix of the governing Darwinian theory. An organism is the locus of values defended; life is otherwise unthinkable. But this is value individualized, or, to put it more provocatively, piecemeal value. Darwinian value comes in particulars, packed into individuals who survive and flourish, adapt and die, and regenerate themselves. We do find golden eggs, but we are not sure whether there is a systemic goose. If there is, it looks as though the goose lays eggs chaotically; and when they hatch, things at once become ugly, "red in tooth and claw."

Francis Crick complains that biology is not "elegant." As organisms evolve through that interplay of chance and necessity called evolution, they become encrusted with mechanisms and tricks that might have no overarching logic. An organism has an accidental history in a way that an atom or a galaxy does not (Crick 1988, 6, 137-42). Despite finding pandas and orchids among his chance riches, Gould claims that the panda's thumb is makeshift and that orchids are "jury-rigged" (1980c, 20-21). François 
Jacob characterizes evolutionary history as millennia of "tinkering" (1977).

But, if we return to basic Darwinian theory, biologists do have niches into which each of these organisms must be placed as an "adapted fit." That invites thinking about the interdependence and community in which organisms participate. If so, we need to move from " $x$ has a value of its own" to " $x$ is valuable in the system." If $x$ serves a role as an adapted fit, we might often find that $x$ expresses some value not otherwise present in the system, enriches it by being there.

Of course, it might be that $x$ has a value of its own but that the pursuit of that value is bad for the system, or bad for people. That $x$ has a good of its own does not entail that the good of $x$ should be promoted. Disease germs have a good of their own, but we do not wish to promote that good. The first is a fact, the second is a normative judgment.

With a more systemic set of facts, however, diseases are parasitic on a larger wealth of biodiversity. Parasitism is a subroutine in a larger valuecapture system. The whole idea of parasitism is conceptually parasitic on values elsewhere present and flourishing enough to be parasitized. The parasite that loses skills borrows those skills because these remain in the host. The disvalue, parasitism, is privative on some value, autonomous life; and all life is interdependent.

Seldom does the system as a whole degenerate. Sometimes it may, as when climates turn colder or drier, but even then new skills appear. On planetary scales there is that overall increase of diversity and complexity we earlier considered. If one values life at all, one must value it genetically, collectively, as with the term biodiversity. Every individual organism, presumably, is a distributive increment in a collective good. The burden of proof will be on those who single out germs-or skunks, weasels, or poison oak - as bad kinds. For the most part, these swarms of creatures are very good-as is affirmed early in the book of Genesis.

Whether biologists can find such selective principles or not, it seems that something is at work making the system fertile, prolific, and developmental, combining both innovations and novelties with stabilities and regularities so as to order the story and perpetuate a swelling wave. This portrays in some respects a loose teleology, a soft concept of creation, yet one that permits genuine, though not ultimate, integrity and autonomy in the selfdeveloping creatures. What comes to pass wells up from below, congealing out of the quantum states. After that welling up is underway the higher levels can also come to superintend the lower, responding to potentials presented there, as when an organism with its genetic program executes its lifestyle, commands and puts to use resources in its metabolism. The life adventure overall seems more an interaction phenomenon, where a prolife principle is overseeing the affairs of matter.

Theories are like suits of clothes; they do have to more or less fit the data, but a great deal depends on how you want to dress things up. Maybe 
you want to dress up randomly and chaotically. Maybe you want to dress up red with tooth and claw. Maybe you want to dress nature up with "selfish genes" (Dawkins 1989), defending local values in a system where conflict and combat is all that one can see. But there is another way to dress nature up, as seen in those conservation biologists ready to rejoice in the richness of biodiversity.

When we celebrate biodiversity and wonder whether there is a systemic tendency to produce it, biology and theology become natural allies. The classical theology of design perhaps needs reforming, but the biology of randomness and bloody struggle may need reforming just as much. The paradigms need to change; and to that end, I argue that the better biological categories are those of values achieved, actualized, shared, and conserved in a natural history of dramatic creativity. Such a reinterpreted biology will be much more congenial to theology. The facts may give us, so to speak, sufficient cause to wonder about reverence for creation. Where there is creativity, we will have to wonder whether there may lurk a Creator.

\section{EARTH AS PROVIDING GROUND}

Every animal, every plant has to seek resources, but life persists because it is provided for in the system. Earth is a kind of providing ground. I am choosing my words deliberately, if also provocatively. Ground has an earthy tone, along with a cosmic possibility. Life needs an earthy "grounding," and when we find how prolific Earth is, we need some metaphysical "ground" of such a nature.

Provide has echoes of "providence" and classical theological convictions that God provides for an abundant life and that those provisions include a Promised Land, a garden Earth. Yes, Earth has "provisions"—or, as scientists prefer, resources. But what are we to make of the deeper sources by which there come to be these resources? What are we to make of these provisions for life on Earth, found as facts by science, judged valuable, respected in environmental ethics, even reverenced by ecological theologians? There is biodiversity, plenitude of being, because Earth is a "re source-full" place. How does this come to be? If we can answer that, we may want to go on to ask, Why does this come to be?

Physics has discovered the so-called fine-tuned universe. Astrophysics and nuclear physics, combining quantum mechanics and relativity theory, have made dramatic discoveries at both astronomical and submicroscopic levels. Recent theory interrelates the two levels; astronomical phenomena., such as the formation of galaxies, stars, and planets, depend critically on microphysical phenomena. Events at the mid-range scales, where the known complexity on Earth mostly lies (in ecosystems or human brains), depend on the interacting microscopic and astronomical ranges.

These results have been summarized as the anthropic principle, which argues that the universe has been configured from the start in the funda- 
mental characteristics of its construction for the subsequent construction of stars, planets, life, and mind. (For summaries of a large literature, see Barr 2001; Leslie 1989). There are naturalistic ways of interpreting these discoveries, which, rather curiously, typically multiply universes generously enough so that our prolific universe can be a rare piece of good luck-one among myriad stillborn universes. By this account, not only are the achievements of evolutionary history on Earth, starting some five billion years ago, mostly a matter of luck; even more, some ten billion years before that, getting the kind of universe started up that would later become a providing ground is fantastically lucky.

If one is a metaphysician unhappy with multiplying other speculative and otherwise unknown universes sufficiently that we can have this one by luck, then one needs to look more closely at the remarkable features of this one that make it possible for there eventually to be life. But now the luck problem returns in events within our home universe. It is difficult to tell whether these astronomical and microphysical relationships are necessary or contingent, or both. So far as these relations are necessary, we seem to have some pro-life principle there before the startup; so far as they are contingent, we seem to need some pro-life principle appearing as life gets underway. There is already at the astronomical levels this readiness for life, in the sense of constructing the sorts of atoms that-as we later discover, but so far only on Earth — can be organized this way.

Contingent or necessary, on Earth we have the dramatic result that life and mind are absolutely dependent on some deep structure that makes this universe right for life. None of this prevents an inquiry, beyond the natural, into why there is this natural and improbable or inevitable prolific universe. We live in what K. G. Denbigh (1975) calls "an inventive universe." But that there exists a universe with such a fundamental makeup nowhere seems necessary or self-explanatory, either in its fundamental astronomical makeup or in the specifics of events on Earth.

A striking property is that the universe is prone to form pacts of energetic matter: stars, assembled in galaxies - and these stars have served as furnaces in which all of the higher elements have been forged, with a cooking time of many millions of years. The products have included carbon, oxygen, nitrogen, iron, silicon, and other elements in proportions that later have proved fortuitous for evolving dirt and, out of the dirt, life. But life needs a place to happen, and such places are not so easy to find.

Located at a felicitous distance from the sun, Earth has liquid water, atmosphere, a suitable mix of elements, compounds, minerals, and an ample supply of energy. Radioactivity deep within the planet produces enough heat to keep its crust constantly mobile in counteraction with erosional forces, and the interplay of such forces generates and regenerates landscapes and seas-mountains, canyons, rivers, plains, islands, volcanoes, estuaries, continental shelves. 
On Earth, life appears. The know-how for life is coded into genetic sets, which are not present in rocks, clouds, or stars. An organism is a spontaneous cybernetic system, self-maintaining with a control center, sustaining and reproducing itself on the basis of information about how to make a way through the world. Organisms employ physical and chemical causes, but, distinctive to life, there is information superintending the causes. This information is a modern equivalent of what Aristotle called formal and final causes; it gives the organism a telos, an end, though not always a felt or conscious end. A major discovery of biologists in the last half century has been massive amounts of information coded in DNA, a sort of linguistic molecule.

Physics is often taken to be the ultimate science. It also is the simplest of the sciences, in the sense that it leaves out all of the later and higherlevel complexities to focus on the search for what is "down under," for the elemental particles and processes out of which everything came. But we do not hit any rock bottom at the start; we just quit in physics, because there is no more fundamental science to which to turn. And sometimes we fail to realize how a fundamental element in the story is not present in physics at all.

In nature, there were once two metaphysical fundamentals: matter and energy. The physicists reduced these two to one: matter-energy. The biologists shortly afterward discovered that there were still two metaphysical fundamentals: matter-energy and information. Norbert Wiener insists, "Information is information, not matter or energy" (1948, 155). George C. Williams is explicit: "Evolutionary biologists have failed to realize that they work with two more or less incommensurable domains: that of information and that of matter. ... The gene is a package of information" (quoted in Brockman 1995, 43).

Maynard Smith writes, "Heredity is about the transmission, not of matter or energy, but of information" $(1995,28)$. The most spectacular thing about planet Earth, says Richard Dawkins, is this "information explosion," even more remarkable than a supernova among the stars $(1995,145)$. Klaus Dose adds that, after more than thirty years of experimentation on the origins of life, we have only "a better perception of the immensity of the problem rather than its solution. ... We do not actually know where the genetic information of all living cells originates" (1988, 348).

When sodium and chlorine are brought together under suitable circumstances, anywhere in the universe, the result is salt, sodium chloride. No information input is needed. When nitrogen, carbon, and hydrogen are brought together under suitable circumstances anywhere in the universe, with energy input, the spontaneous result may be amino acids, but it is not hemoglobin molecules or lemurs - not spontaneously. The knowhow, so to speak, to make salt is already in the sodium and chlorine, but the know-how to make hemoglobin molecules and lemurs is not secretly 
coded in the carbon, hydrogen, and nitrogen. The essential characteristic of a biological molecule, contrasted with a merely physicochemical molecule, is that it contains vital information. All such information once upon a time did not exist, but came into place. This is the locus of creativity.

In the ongoing story, especially after biology arrives with its genetic capacities to store information, transitioning across those levels noted by Maynard Smith, we keep getting more out of less. The ultimate phenomenon to be explained is not really energy physics but information history, especially the natural history on Earth. The creativity in nature is poorly authorized by the best causal accounts; there is little or no imperative for the commanding drama. We get lots of explanations, yet the sense of mystery does not go away.

Theologians, when they turn from conversing with physicists to dialogue with biologists, will want to notice that, although the physical universe is necessary for life, perhaps even fine-tuned for life, this physical universe is not yet known to be sufficient for life. Indeed, so far as we yet know, life has occurred only in the tiniest fragment of it. The universe as a whole is quite lifeless. Even if there is extraterrestrial life, life will still be among the rarest things in the universe. Earth stands somewhere midscale in the spectrum of levels from quarks to galaxies, and at this midscale take place the most complex events known anywhere in the universe. We seem to reside on some providing ground, and Earth seems to be an intense expression of how dramatic these provisions can be. Earth is indeed a promising planet. But if we claim that science is explaining how, much less why, this is so, we are only holding out a promissory note. Such a promissory note must compete with religious explanations of Earth's creativity.

We can, we ought to, respect such creativity. If we see nature only instrumentally, we are inclined to manipulate it, our providing ground, our provisions. If we see these evolutionary and cybernetic processes and the resulting products, Earth's biodiversity, more deeply as having intrinsic value, we are inclined to respect it, and we may pass over unawares to reverence for life. If we come to systematically venerate the productive processes, the Ground that provides for life, we have passed into the domain of the religious.

\section{CRUCIFORM CREATION}

Next, we move from provision to struggle. Darwinian natural history reveals an ambiguity in life. Life is provided for in the system and is simultaneously a ceaseless struggle; new life is generated by blasting the old. Darwinians may accentuate the competition, "nature red in tooth and claw." Darwin as well portrays connectedness: common ancestry, survival of the best adapted, life support in ecosystems. Darwin portrays life persisting in 
the midst of its perpetual perishing, life generated and regenerated in spectacular biodiversity and complexity, with exuberance displayed over three and a half billion years, an abundance of life. Such a view of life echoes ancient religious motifs: Life is a table prepared in the midst of enemies, green pastures in the valley of the shadow of death (Psalm 23).

Darwin himself contains much of this ambivalence:

Thus, from the war of nature, from famine and death, the most exalted object of which we are capable of conceiving, namely, the production of the higher animals, directly follows. There is a grandeur in this view of life, with its several powers, having been originally breathed into a few forms or into one; and that, whilst this planet has gone cycling on according to the fixed law of gravity, from so simple a beginning endless forms most beautiful and most wonderful have been, and are being, evolved. (Darwin [1859] 1968, 459-60)

Darwin also exclaims that the process is "clumsy, wasteful, blundering, low, and horribly cruel" (quoted in de Beer 1962,43).

There is such ambivalence already present in the Bible. Often the Bible extols the beauties of creation: "O Lord, how manifold are thy works! In wisdom hast thou made them all; the earth is full of thy creatures" (Psalm 104:24 RSV). Nature is a wonderland-perhaps not a paradise, but a realm to be encountered in awe. Alongside these passages we also find laments over creation. Nature, sighs the Preacher, is "vanity of vanities" (Ecclesiastes 1:2 RSV). "The whole creation," asserts Paul, "has been groaning in travail together until now. ... The creation was subjected to futility" (Romans 8:22, 20 RSV).

In chemistry, physics, astronomy, geomorphology, and meteorology, nothing suffers; in botany, life is stressed; but only in zoology does pain emerge. Genes do not suffer; organisms with genes need not suffer; but those with neurons do. One is not much troubled by seeds that fail to sprout, but it is difficult to avoid pity for nestling birds fallen to the ground. In every season, most of the sentient young starve or are eaten or abandoned. Life is indisputably prolific; it is just as indisputably pathetic (Greek pathos), almost as if its logic were pathos. The fertility is close-coupled with the struggle.

Suffering is a troubling fact, but the first fact to notice is that suffering is the shadow side of sentience, felt experience, consciousness, pleasure, intention, all the excitement of subjectivity waking up inexplicably from mere objectivity. Rocks do not suffer, but the stuff of rocks has organized itself into animals who do experience pains and pleasures. We may wonder why we suffer, but it also is quite a wonder that we are able to suffer. Something stirs in the cold, mathematical beauty of physics, in the heated energies supplied by matter, and there is first an assembling of living objects and later of suffering subjects. Energy turns into pain. The world begins with mere causes; it rises to generate concern and care. 
With such concern, turning (as we now do) to wonder whether to respect such a nature, perhaps this is ugliness emergent? Or are we perhaps encountering a valuable good, sentient life, with its inevitable dark side? Pain is objectively present in nature, and what is its connection with genesis? Struggle is the dark side of creativity-logically and empirically the shadow side of pleasure. One cannot enjoy a world in which one cannot suffer any more than one can succeed in a world in which one cannot fail. The logic is not so much formal or universal as it is dialectical and narrative. In natural history, the pathway to psychosomatic consciousness - the only kind of experience we know-is through flesh that can feel its way through that world. An organism can have needs; inert physical nature cannot. If the environment can be a good to it, that brings also the possibility of deprivation as a harm. To be alive is to have problems. Things can go wrong precisely because they can also go right.

Sentience brings the capacity to move about deliberately in the world, and also to get hurt by it. There might have evolved sense organs without any capacity to be pained by them. But sentience has not evolved to permit mere observation of the world but rather to awaken some concern for protection of the kinesthetic core of an experiential life that can suffer. A neural animal can love something in its world and is free to seek it. This capacity is greatly advanced over anything known in immobile, insentient plants. The appearance of sentience is the appearance of caring when the organism is united with or torn from its loves. The story is not merely of goings on but of going concerns, that is, of values that matter. The evolution of caring - and, inseparable from this, of suffering-is the evolution of the capacity to respect life-first one's own life, and in due course the lives of others.

The system historically uses pain for creative advance. Such is the biology of life. We can subsume struggle under the notion of a comprehensive situated fitness. We begin to get a new picture painted over the old, although some of the old picture still shows through. Theologically speaking, this position is not inconsistent with a theistic belief about God's providence; in fact, it is in many respects remarkably like it. There is grace sufficient to cope with thorns in the flesh (2 Corinthians 12:7-9).

The community of life is continually regenerated, as well as creatively advanced, and this requires value capture as nutrients, energy, and skills are shuttled around the trophic pyramids. From a systemic point of view, this is the conversion of a resource from one life stream to another-the anastomosing of life threads that characterizes an ecosystem. The "waste" (as it first appears) is really the systematic interconversion of life materials; nature recycles. Death in vivo is death ultimately; death in communitatis is death penultimately but life regenerated over the millennia of species lines and dynamic biotic communities, millennia continuing almost forever. 
Genera and species sometimes die (that is, go extinct without issue), but often they are transformed into something else, new genera and species; they are rejuvenated. On average, there have been more arrivals than extinctions, an increase in both diversity and complexity over evolutionary history. The loss of species in natural systems has meant more birth than death. Perhaps there, too, it is tragic, but it is not unredeemed tragedy. The birthing metaphor is at the root of the etymology of nature; here creativity comes only with "labor" and "travail," which was Paul's metaphor for regeneration and newness of life.

The world is not a paradise of hedonistic ease but a theater where life is learned and earned by labor. In this struggle there is something demanding appropriate respect, something inviting reverence, something divine about the power to suffer through. The cruciform creation is, in the end, deiform, godly, because of this element of struggle, not in spite of it. Among available theories, there is no coherent alternative model by which, in a painless world, there might have come to pass anything like these dramas of nature and history that have happened, events that in their central thrusts we greatly value.

An environment that was entirely hostile would slay us; neither life nor culture could ever appear there. A nature that was entirely irenic would stagnate us; human life could never have appeared there, either. All human culture, in which our classical humanity consists, originated in the face of oppositional nature. Nature insists that humans work, and this laboring and even suffering is its fundamental power for genesis. Creativity is through conflict and resolution. We suffer, and, lest we suffer more, we organize ourselves creatively. In that sense, humans owe all culture to the hostility of nature, provided we keep in tension with this the support of nature that is truer still, the one the warp, the other the woof, in the weaving of what we have become.

The distinctive characteristics of the human spirit make tragedy and redemption possible. Birth is superseded by rebirth and the question of generation by the question of regeneration. Any adequate interpretation of this story of spirits fallen into tragedy and redeemed from this fall is going to be irreducibly religious. This is the essential theme of Christianity and Judaism, for example, that suffering love is divine. We doubt whether biology is competent to evaluate whether this is true or false, although it is competent to document the struggle for survival, the sequence of life, death, and life renewed. Zoology, perhaps joined with psychology, can raise the problem of suffering, but its redemption is a religious issue.

Before there was culture and human redemption the way of natural history was already a via dolorosa. Since the beginning, myriad creatures have been giving up their lives as a ransom for many. In that sense, Jesus is not the exception to the natural order but a chief exemplification of it. The secret of life is seen now to lie not so much in heredity molecules, or 
in natural selection and the survival of the fittest, or in life's informational, cybernetic learning. The secret of life is that it is a passion play. This is the labor of divinity, and it is misperceived if seen only as selfish genes or red tooth and claw. The view here is not panglossian; it is a tragic view of life, but one in which tragedy is the shadow of prolific creativity. That is the case, and the biological sciences with their evolutionary history can be brought to support this view, although neither tragedy nor creativity is part of their ordinary vocabulary.

We celebrate the richness of biodiversity on Earth. We respect life and come, at the depths, to reverence this struggle for life. The Prologue to the Gospel of John opens with the divine logos, through which all things were made, coming where it already was. This divine informing of nature is, we could say, a cybernetic metaphor. The Prologue continues: "The light shines in the darkness, and the darkness has not overcome it" (John 1:5 RSV). I would find it difficult better to describe, in poetic metaphor, the course of evolutionary natural history.

\section{NATURE AS GRACE}

Nature is struggle. Nature is grace. I recall, in the Appalachian woods, stumbling upon a whorled pogonia flowering in spring in a secluded glade and exclaiming, "Amazing grace!" Life persisting in the midst of its perpetual perishing is a kind of gift. Scientists may prefer the word given to gift, and they will definitely prefer law to grace. The secular will say only that life is a given, and also perhaps that one ought to respect such a given. But the religious will think that gift is more insightful than just a given. And then we may need a Giver with the gift, or, if that is too monotheistic, at least some metaphysical explanation that seems adequate to what is given.

There is creativity by which more comes out of less. Though the system provides for it, no logic demands it. Scientific theory doubtfully predicts it. Actually, neither scientific logic nor theory handles historical explanations very competently, especially where there are emergent novelties; science prefers lawlike explanations in which there are no surprises. Given initial conditions, one predicts, logically unfolding one's theory, and the prediction comes true. Nevertheless, biology is full of unpredictable surprises. The account of natural history will not be by way of implication, whether deductive or inductive. There is no covering law (such as natural selection), plus initial conditions (such as trilobites), from which one can deduce primates, any more than one can assume microbes as a premise and deduce trilobites in conclusion. There are no humans invisibly present (as an acorn secretly contains an oak) in the primitive eucaryotes, to unfold in a lawlike or programmatic way. All we can do is tell the epic storyeucaryotes, trilobites, dinosaurs, primates, persons who are scientists, ethicists, and conservation biologists - and the drama may prove enough to justify it. 
True, there are scientists who see earthen natural history as inevitable, as a systemic given. Christian de Duve writes, "Life was bound to arise under the prevailing conditions, and it will arise similarly wherever and whenever the same conditions obtain. There is hardly any room for 'lucky accidents' in the gradual, multistep process whereby life originated. ... I view this universe [as] . . . made in such a way as to generate life and mind, bound to give birth to thinking beings" (1995, xv, xviii).

"This universe breeds life inevitably," concludes George Wald (1974, 9). Life appears, claims Melvin Calvin, "not by accident but because of the peculiar chemistries of the various bases and amino acids. . . . There is a kind of selectivity intrinsic in the structures." The evolution of life is "a logical consequence" of natural chemistries (1975, 176, 169). Manfred Eigen concludes "that the evolution of life . . . must be considered an inevitable process despite its indeterminate course" $(1971,519)$.

Simon Conway Morris is recently the most vigorous, and, among paleontologists, the most anomalous in his seemingly certain conviction that human life has appeared only on Earth but did so here as a law of the universe: We are "inevitable humans in a lonely universe." "Life ... is full of inherences," precursors of later unfolding tendencies. "Life shows a kind of homing instinct." He builds his case on evolutionary convergences. "All the principal properties that characterize humans are convergent" (Conway Morris 2003, 8, 20, 96).

Given time, evolution will inevitably lead not only to the emergence of such properties as intelligence, but also to other complexities, such as, say, agriculture and culture. ... We may be unique, but paradoxically those properties that define our uniqueness can still be inherent in the evolutionary process. In other words, if we humans had not evolved then something more-or-less identical would have emerged sooner or later. $(2003,196)$

Such accounts suggest that the history is predestined, but this outcome is seen only retrospectively. Even if some scientist had been able to observe the elementary particles forming after the first three minutes, nothing much in them would have suggested anything specific about the coding for life that would take place, fifteen billion years later, on Earth. Only much later do scientists arrive on the scene and posit the anthropic principle that finds the materials right for life.

After Earth's formation, as the lifeless planet is being irradiated by solar energy (as are other planets), quantum physics depicts an open system and nested sets of possibilities; but all of the atoms and molecules take nonliving tracks. Only later do some atoms and molecules begin to take living tracks, called forth as interaction phenomena when cybernetic organisms appear. If there is some "inside order" (inherency) to matter that makes it pro-life, it is in the whole system, not just in the particles. But this is not evident in systemic astronomy, since by far the vastest parts of the universe are lifeless (the "lonely universe"). Life is an earthbound probability. Nor, 
on Earth, are the meteorological or geomorphological systems all that suggestive of inevitable life. Biology seems to open up entirely unprecedented levels of achievement and power.

There is not much in the physics and chemistry of atoms and molecules, prior to their biological assembling, that suggests that they have any tendencies to order themselves up to life. Even after things have developed as far as the building blocks of life, there is nothing in a thin hot soup of disconnected amino acids to predict that they will connect themselves, or be selected along upward, negentropic though metastable courses into proteins, or that they will arrange for DNA molecules in which to code the diverse forms of life, or that these molecules will discover how to code dinosaurs, primates, and persons. We are unsure how the gift is given or even whether, either in the universe or on Earth, all this natural history is some kind of given. Scientists do not know whether Earth's biodiversity is chance riches or a systemic inevitability. Meanwhile, we discover a wonderland-and discover in ourselves a metaphysical wonder whether this could be grace.

In claiming that nature is grace I must deal not only with scientists but often also with theologians who are unable to find grace in nature, indeed unable even to find value there, until they have been so authorized by divine revelation. Here is Keith Ward, a theologian: "I do think that nature has to have intrinsic value because God has created it. If there were not a God, if I did not believe in God, I would not think that nature had any intrinsic value. . . . I would have an instrumentalist view, actually" $(2002,14)$. The claim seems to be that, until one has insight from elsewhere, one will not know what to make of nature. After one gets converted, one can love nature for what it is in itself, but any who think they are warranted in loving nature before they are converted are just confused. All the unconverted can do is use nature instrumentally. That does not seem to approach even respect, much less reverence. But Paul Taylor, a philosopher, has a celebrated argument for biocentrism: Respect for Nature (1986). In it there is no suggestion of reverence.

So, how far can we get toward the conviction that nature is grace, left to our own wits? Maybe we can get halfway there with another experience: the sense of the sublime. Sublime is today thought to be an archaic word. But that word has a way of reappearing when we really get archaic in the deep sense- that is, back to the archetypes - which happens more often in the wilderness than in town. The experience of the sublime literally "takes us to the limits" and is closer to mystery and the religious than to mere respect. Nature is the first mystery to be encountered; society comes later, much later, after one learns evolutionary history. In the primeval forest, or on the desert or tundra, humans get transported by forces awful and overpowering, by the signature of time and eternity. 
"The trees of the Lord are watered abundantly; the cedars of Lebanon which he planted" (Psalm 104:16 RSV). With forests, America is even more of a promised land than is Palestine. John Muir exclaimed, "The forests of America, however slighted by man, must have been a great delight to God; for they were the best he ever planted" (1901, 331). Such forests are a church as surely as they are a commodity. Trees pierce the sky like cathedral spires. Light filters down as through stained glass. The forest canopy is lofty; much of it is over our heads. In common with churches, forests invite us to transcend the human world and experience a comprehensive, embracing realm. "The groves were God s first temples" (Bryant [1825] 1903,79).

So, far from being unaware that nature is grace until after one has been to church, for many it is the other way around. Forests serve as a more provocative and perennial sign of the mysterious and the awesome than many of the traditional, often outworn, symbols devised by the churches. Muir commented, "The clearest way into the Universe is through a forest wilderness" (quoted in Wolfe 1938, 313). Christians would regard that as an overstatement; for them the clearest way into the Universe is though Jesus Christ.

But Christians may also remember that Jesus saw the presence of God clearly in the natural world in which he resided. The birds of the air, he said, neither sow nor reap yet are fed by the heavenly Father, who notices the sparrows that fall. Not even Solomon is arrayed with the glory of the lilies, though the grass of the field, today alive, perishes tomorrow. There is in every seed and root a promise. Sowers sow, the seed grows secretly, and sowers return to reap their harvests. God sends rain on the just and unjust. Divinely given, earthen nature is the original act of grace.

Being among the archetypes, a forest is about as near to ultimacy as we can come in the natural world - a vast scene of sprouting, budding, flowering, fruiting, passing away, passing life on. We get goose pimples with mountaintop experiences, hearing the wind in the pines, with solitude in a sequoia grove, watching the falling autumn leaves. We feel life's transient beauty sustained over chaos. A forest wilderness is a sacred space. There Christians recognize God's creation (perhaps cued to look for it when they were back in church at the altar). Others may find an Ultimate Reality, or a Nature sacred in itself. A forest wilderness elicits cosmic questions differently from town, and it seems to do this whether we have been reading our Bibles or not. Christians ought to have a particular interest in preserving wildlands as sanctuaries for religious experiences, both for Christians and for others inspired there.

If the word sublime is too archaic for modernists who visit the woods, perhaps we can get halfway to the sacred with the word wonder. If we wonder at nature, do we not thereby consider nature a wonderland? A wildland is a wonderland, standing on its own. "Praise the Lord from the 
earth, you sea monsters and all deeps, fire and hail, snow and frost, stormy wind fulfilling his command! Mountains and all hills, fruit trees and all cedars! Beasts and all cattle, creeping things and flying birds!" (Psalm 148: 7-10 RSV) "Thou crownest the year with thy bounty; the tracks of thy chariot drip with fatness. The pastures of the wilderness drip, the hills gird themselves with joy, the meadows clothe themselves with flocks, the valleys deck themselves with grain, they shout and sing for joy" (Psalm 65:1113). "Who has cleft a channel for the torrents of rain, and a way for the thunderbolt, to bring rain on a land where no man is, on the desert in which there is no man; to satisfy the waste and desolate land, and to make the ground put forth grass?" (Job 38:25-27).

Gould finds Earth the scene of ${ }^{£}$ wonderful life," even if this is just "chance riches" (Gould 1989; 1980b). Indeed, in the last words he wrote, he was moved to use the word holy:

Something almost unspeakably holy_-I don't know how else to say this- underlies our discovery and confirmation of the actual details that made our worlds and also, in realms of contingency, assured the minutiae of its construction in the manner we know, and not in any one of a trillion other ways, nearly all of which would not have included the evolution of a scribe to record the beauty, the fascination, and the mystery. (Gould 2002, 1342)

E. O. Wilson, a secular humanist, ever insistent that he can find no divinity in, with, or under nature, still exclaims, with emphasis: "The flower in the crannied wall-it is a miracle" (Wilson 1992, 345). "The biospheric membrane that covers the Earth, and you and me,... is the miracle we have been given" (Wilson 2002, 21). Daniel Dennett, as resolute a naturalist as one can find, still ends his survey of natural history: "This world is sacred." Apparently not even Darwin s "universal acid" can dissolve that claim, dissolve God though this acid can (Dennett 1995, 520-21).

Maybe these code words, miacle, sacred, and holy., are just rhetoric; maybe they are provocative. But I suspect that even these three secularists are tugged by a deeper undertow than they realize in their encounters with these archaic orders. The secular-this present empirical epoch, this phenomenal world, studied by science-does not eliminate the sacred after all; to the contrary, the secular evolves into the sacred. Surveying paleontological history, Loren Eiseley exclaims, "Nature itself is one vast miracle transcending the reality of night and nothingness" (I960, 171).

Viewing Earthrise from the moon, astronaut Edgar Mitchell was entranced: "Suddenly from behind the rim of the moon, in long, slow-motion moments of immense majesty, there emerges a sparkling blue and white jewel, a light, delicate sky-blue sphere laced with slowly swirling veils of white, rising gradually like a small pearl in a thick sea of black mystery. It takes more than a moment to fully realize this is Earth . . . home." Mitchell continued, "My view of our planet was a glimpse of divinity" (quoted in Kelley 1988, at photographs 42-45). Astronaut 
Michael Collins recalled being Earthstruck: "Earth is to be treasured and nurtured, something precious that must endure" (Collins 1980, 6).

These are astronauts, not biologists, but what they see is the home planet, the living planet in all its startling possibilities, of which evolutionary history is the most indisputable evidence. The vision of the land of promise originated in Israel. What we have discovered is that this is a global vision. The land of promise is the planet of promise.

\section{GENESIS AND CREATIVITY}

The creative action once reserved to God's special creation of fixed species must now be reallocated to include a vast self-creativity within the creatures, lured upslope over this long evolutionary process. What theologians once termed an established order of creation is, rather, a natural order that dynamically creates, an order for creating. The older and newer accounts concur that living creatures now exist where once they did not. But the manner of their coming into being has to be reassessed. God is not, craftsman-like, molding the material. But God "from below" microscopically creates the energetic, pro-life materials that bubble up trials. "From above," systematically and environmentally, God, perhaps via selectivity intrinsic in the processes, perhaps by divine "inspiration" (=informing), coaxes forth living organisms and, via natural selection, selects the best adapted.

Biologists find biological creativity indisputable, whether or not there is a Creator. Biologists have no wish to talk theologians out of genesis. Whatever one may make of God, biological creativity is indisputable. There is creation, whether or not there is a Creator, just as there is law, whether or not there is a Lawgiver. Sometimes biologists decline to speak of creation, because they fear a Creator lurking in the concept of creation. Well, at least there is genesis, whether or not there is a Genitor. Ultimately, there is a kind of creativity in nature demanding that we either spell nature with a capital $N$ or pass beyond nature to nature's God. Biologists today are not inclined, nor should they be as biologists, to look for explanations in supernature, but biologists nevertheless find a nature that is super! Superb! Science teaches us to eliminate from nature any suggestions of teleology, but it is not so easy for science to talk us out of genesis. What has managed to happen on Earth is startling by any criteria. Biologists may doubt whether there is a Creator, but no biologist can doubt genesis.

Many resist the idea that value has to be introduced from outside nature. Biologists and physicists wish to have causes emanating from their own domains, and they have often persuaded theologians too that, surprising as these phenomena are, they are nevertheless natural. So, Gordon Kaufman speaks of the "serendipitous creativity" that seeps through the universe, but he nevertheless wishes to remain a theological naturalist (Kaufman 1993, chaps. 19, 20). Use the word God as a "symbol" for these 
remarkable processes, if you wish (perhaps rather like Wilson with his "miraculous flower," Gould with his "holy" evolutionary history, or Dennett with his "sacred world"), but do not try to detect God the Father transcendent to this serendipity. Rather, celebrate nature as the source of this serendipitous process-like gravity, except negentropic. This bioforce pulls things upward to higher and higher forms.

Kaufman then finds himself "in face of mystery" (1993) and marvels at the serendipity on Earth. But serendipity is not an explanatory concept. It just baptizes the natural phenomena with a fairy tale word. ${ }^{1}$ It puts the spectacular creative events down to extraordinarily good luck. If we are to have a real explanation, we need to detect something "extra" lurking within the serendipitous process. We can say, if we like, that with the appearance of life, or photosynthesis, or warm-blooded animals, or endoskeletons, or fat cells, or immunoglobin molecules, or psychological inwardness, there is just serendipity, more serendipity, cascading serendipity. But that is not an explanation; it is a confession that we do not have any adequate explanation. Nothing we know in science, certainly not in biology and just as doubtfully in physics, authorizes any scientific theory of nature that is "up to" these events that are the surprising facts of natural history. If you wish a nature with that power, you must be religious about it.

Neither physical nor biological discoveries of pathways of development do much to make nature self-explanatory. We find causes necessary but not sufficient. The rejoinder to Where is the Presence? is Where is the explanatory adequacy of a self-contained physics or a self-contained biology? Evidence that nature is not self-explanatory can be seen at all its creative loci. Three especially dramatic places: (1) In physics, once upon a time there was the origin of matter-energy. (2) In biology, once upon a time there was the origin of life, first during the era of chemical evolution, with the elaboration of life over many subsequent millennia. (3) In neurobiology, once upon a time there was the origin of subjective life, of felt experience. Each time, there is created something novel. Perhaps at the origin of life and the origin of mind we can give some story of the assembly of parts, how possibly this novel event came to take place historically. But these are never why-necessarily explanations; we are always getting conclusions that exceed what is precontained in the premises.

The secular autonomy that once seemed to banish any Presence turns out to veil, a kind of haunting incompleteness. True, there are always some causes behind effects, but these nevertheless have surprising, serendipitous effects that the causes never seem to completely specify. The stream steadily rises above its source. The effects over time, whether probable or improbable, initiate events the likes of which have nowhere been seen before.

In this deeper sense, says Ernst Mayr, though hostile enough to traditional monotheism, "virtually all biologists are religious, in the deeper sense of the word, even though it may be a religion without revelation. ... The 
unknown and maybe unknowable instills in us a sense of humility and awe" (1982, 81). "I would say," writes Loren Eiseley at the end of The Immense Journey, "that if 'dead' matter has reared up this curious landscape of fiddling crickets, song sparrows, and wondering men, it must be plain even to the most devoted materialist that the matter of which he speaks contains amazing, if not dreadful powers, and may not impossibly be ... 'but one mask of many worn by the Great Face behind"' (Eiseley 1957, 210). The molecular self-assembling of organisms over evolutionary history is a sort of self-actualizing, but it is also a response to the brooding winds of the Spirit moving over the face of these earthen waters.

Once J. B. S. Haldane found himself in conversation with some theologians and was asked what he had concluded from his long studies in biology about the character of God. He replied that God had an inordinate fondness for beetles. God must have loved beetles, he made so many of them. But species counts are only one indication of diversity, and perhaps the fuller response is that God must have loved life, God animated such a prolific Earth. Haldane went on to say that the marks of biological nature were its "beauty," "tragedy," and "inexhaustible queerness" (Haldane 1932, 167-69). This beauty approaches the sublime; the tragedy is perpetually redeemed with the renewal of life, and the inexhaustible queerness recomposes as the numinous.

Biology produces many doubts; here are two more, I doubt whether one can be a biologist without a respect for life, and the line between respect for life and reverence for life is one that I doubt that we can always recognize and one that is more important than we think. If anything at all on Earth is sacred, it must be this enthralling creativity that characterizes our home planet. If anywhere, here is. the brooding Spirit of God.

\section{NOTE}

This article is a version of an address given at the American Academy of Religion in Atlanta, Georgia, November 2003.

1. The word serendipity was coined by Horace Walpole after the characters in the Persian fairy tale The Three Princes of Serendip who were always making fortunate and unexpected discoveries by accident.

\section{REFERENCES}

Ayala, Francisco J. 1974. "The Concept of Biological Progress." In Studies in the Philosophy of Biology, ed. Francisco Jose Ayala and Theodosius Dobzhansky, 339-55. New York: Macmillan.

Barr, Stephen M. 2001. "Anthropic Coincidences," First Things 114 (June/July): 17-23.

Brockman, John. 1995. The Third Culture: Beyond, the Scientific Revolution. New York: Simon and Schuster.

Bryant, William Cullen. [1825] 1903. "A Forest Hymn." In The Poetical Works of William Cullen Bryant, 79-82. New York: D. Appleton.

Calvin, Melvin. 1975. "Chemical Evolution." American Scientist 63:169-77.

Collins, Michael. 1980. "Foreword." In Roy A. Gallant, Our Universe. Washington, D.C.: National Geographic Society. 
Conway Morris, Simon. 2003. Life's Solution: Inevitable Humans in a Lonely Universe. Cambridge; Cambridge Univ. Press.

Crick, Francis. 1988. What Mad Pursuit: A Personal View of Scientific Discovery. New York: Basic Books.

Darwin, Charles. [1859] 1968. The Origin of Species by Means of Natural Selection. Baltimore: Penguin.

Dawkins, Richard. 1989. The Selfish Gene. New ed. New York: Oxford Univ. Press. . 1995. River out of Eden: A Darwinian View of Life. New York: Basic Books, Harper Collins.

de Beer, Gavin. 1962. Reflections of a Darwinian, London: Thomas Nelson.

de Duve, Christian. 1995. Vital Dust: The Origin and Evolution of Life on Earth. New York: Basic Books.

Denbigh, K. G. 1975. An Inventive Universe. New York: Braziller.

Dennett, Daniel C. 1995. Darwin's Dangerous Idea. New York: Simon and Schuster.

Dolan, R. J. 2002. "Emotion, Cognition, and Behavior," Science 298:1191-94.

Dose, Klaus. 1988. "The Origin of Life: More Questions Than Answers," Interdisciplinary Science Reviews 13:348-56.

Eigen, Manfred. 1971. "Selforganization of Matter and the Evolution of Biological Macromolecules." Die Natturwissenchaften 58:465-523.

Eiseley, Loren. 1957. The Immense Journey. New York: Vintage Books.

1960. The Firmament of Time, New York: Atheneum.

Gould, Stephen Jay. 1980a. "The Belt of An Asteroid." Natural History 89 (June): 26-33.

․ 1980b. "Chance Riches," Natural History 89 (November): 36-44.

1980c. The Panda's Thumb, New York: Norton.

1983. "Extemporaneous Comments on Evolutionary Hope and Realities." In Darwin's Legacy, ed. Charles L. Hamrum, 95-103. San Francisco: Harper and Row. 1989. Wonderful Life: The Burgess Shale and the Nature of History. New York: Norton. 2002. The Structure of Evolutionary Theory. Cambridge: Harvard Univ. Press.

Haldane, J. B. S. 1932. The Causes of Evolution. Ithaca, N,Y.: Cornell Univ. Press.

Jacob, Francois. 1977. "Evolution and Tinkering." Science 196:1161-66.

Kaufman, Gordon. 1993. In Face of Mystery: A Constructive Theology, Cambridge: Harvard Univ. Press.

Kelley, Kevin W., ed. 1988. The Home Planet, Reading, Mass.: Addison-Wesley.

Leslie, John. 1989. Universes. London: Routledge.

Maynard Smith, John. 1972. On Evolution. Edinburgh: Univ. of Edinburgh Press.

- 1995. "Life at the Edge of Chaos?" New York Review of Books 42 (4): 28-30.

Maynard Smith, John, and Eörs Szathmáry. 1995. The Major Transitions in Evolution. New York: W. H. Freeman.

Mayr, Ernst. 1982. The Growth of Biological Thought. Cambridge: Harvard Univ. Press. . 1988. Toward a New Philosophy of Biology. Cambridge: Harvard Univ. Press.

Muir, John. 1901. Our National Parks. Boston: Houghton Mifflin.

Newell, Norman D. 1963. "Crises in the History of Life." Scientific American 208 (2): 7692.

Niklas, Karl J. 1986. "Large-Scale Changes in Animal and Plant Terrestrial Communities." In Patterns and Processes in the History of Life, ed. D. M. Raup and D. Jablonski, 383405. New York: Springer-Verlag.

- 1997. The Evolutionary Biology of Plants. Chicago: Univ. of Chicago Press.

Raup, David M., and J. John Sepkoski Jr. 1982. "Mass Extinctions in the Marine Fossil Record." Science 215:1501-03.

Ruse, Michael. 1986. Taking Darwin Seriously. Oxford: Basil Blackwell.

․ 1996. Monad to Man: The Concept of Progress in Evolutionary Biology, Cambridge: Harvard Univ. Press.

Taylor, Paul W. 1986. Respect for Nature. Princeton, N.J.: Princeton Univ. Press.

Wald, George. 1974. "Fitness in the Universe: Choices and Necessities." In Cosmochemical Evolution and the Origins of Life, ed. J. Oró et al., 7-27. Dordrecht, Netherlands: D. Reidel.

Ward, Keith. 2002. "Ecology, Christianity and the Future of Creation." Research News and Opportunities in Science and Theology 2 (July/August): 14-16. 
Wiener, Norbert. 1948. Cybernetics. New York: John Wiley.

Wilson, Edward O. 1992. The Diversity of Life. Cambridge: Harvard Univ. Press.

. 2002. The Future of Life. New York: Alfred A. Knopf.

Wolfe, Linnie Marsh, ed. 1938. John of the Mountains: The Unpublished Journals of John Muir. Boston: Houghton-Mifflin. 